\title{
Effects of convective and microwave roasting on the physicochemical properties of cocoa beans and cocoa butter extracted from this material
}

\author{
By W. Krysiak \\ Institute of Chemical Technology of Food, Faculty of Biotechnology and Food Sciences, \\ Technical University of Lodz \\ 90-924 Lodz, 4/10 Stefanowskiego street, Poland \\ e-mail: wieslawa.krysiak@p.lodz.pl
}

\section{RESUMEN}

Efectos del tostado por convección y microondas sobre las propiedades físico-químicas de granos de cacao y de manteca de cacao extraída de ellos.

Granos de cacao de la variedad Costa de Marfil se han sometido a tostado mediante convección y microondas. Se ha estudiado el efecto de las condiciones de tostado sobre los atributos físico-químicos principales (contenido de agua y grasa, acidez total y volátil) del cacao en grano tostado y las propiedades de la grasa extraída de este material (Acidez, índice de saponificación, índice de peróxidos, índice de yodo, índice de refracción, contenido de fracción polar, perfil de ácidos grasos, absorbancia de una solución al 10\% en hexano). Se han comparado las características de los granos de cacao tostados y crudos y sus fracciones lipídicas. Los resultados de los análisis mostraron que el tostado mediante convección durante 35 minutos a $135^{\circ} \mathrm{C}$, con un caudal de aire de $1,0 \mathrm{~m}$ s-1 y HR de 0,45 causó los menores cambios en la calidad de grasa mientras que el tostado mediante microondas promovió en mayor medida la oxidación de los lípidos aunque la calidad de los granos de cacao tostado fue mejor.

PALABRAS CLAVE: Convección - Granos de cacao Manteca de cacao - Microondas - Propiedades físico-químicas - Tostado de granos de cacao.

\section{SUMMARY}

Effects of convective and microwave roasting on the physicochemical properties of cocoa beans and cocoa butter extracted from this material.

The cocoa beans of the Ivory Coast variety were convectively and microwave roasted. The effects of roasting conditions on the principal physicochemical attributes (water and fat contents, total and volatile acidity) of roasted cocoa beans and the properties of fat extracted from this material (acidity, saponification index, iodine index, peroxide value, light refraction coefficient, polar fraction content, and Fatty Acid profile, absorbancy of 1 and $10 \%$ solution in hexane) were examined. The characteristics of roasted and raw cocoa beans and their lipid fractions were compared. Results of analyses showed that convective roasting for $35 \mathrm{~min}$ at $135^{\circ} \mathrm{C}$, air flow rate $1.0 \mathrm{mxs}^{-1}$ and relative humidity $\mathrm{RH}$ of $0.45 \%$ caused the least advanced changes in fat quality while microwave roasting promoted oxidation of lipids although the quality of roasted cocoa beans was the best.

KEY-WORDS: Cocoa beans - Cocoa butter - Convective - Microwave - Physicochemical properties - Roasting of cocoa beans.

\section{INTRODUCTION}

Cocoa beans are the basic raw material for the production of chocolate and other chocolate products. To obtain these products, the seeds must be subjected to a complicated technological process in which one of the key steps is roasting.

A widely used method of roasting cocoa beans is convection roasting which is based on subjecting the raw beans to a flow of hot air in the temperature range between $130-150^{\circ} \mathrm{C}$ for $15-45 \mathrm{~min}$. (Belitz and Grosch, 1999, Minifie 1989, Nebesny and Rutkowski, 1998, Świechowski 1996).

The influence of high temperatures on the beans contributes to many physical and chemical changes that significantly alter their properties. Roasting produces the characteristic aroma of cocoa, the loss of water, volatile acids and tannin compounds, as well as the deepening of the brown color of the bean and the assurance of its microbiological purity (Belitz and Grosch, 1999, Benz, 2002, Jinap et al., 1998, Lee SY. et al., 2001; Minifie 1989, Nebesny and Rutkowski, 1998, Redgwell et al., 2003; Świechowski 1996, Trojanowska and Trojan 1999).

The literature reviews suggest that these features were studied taking into account the general impact of process parameters such as temperature and time. (Brito et al., 2000, 2002, Jinap et al., 1998, Nebesny and Rutkowski, 1998), and only a few works (Krysiak et al., 2003, Krysiak and Motyl-Patelska, 2005) analyzed how other, important process parameters, namely relative humidity and air flow velocity, shaped these changes. The use of increased air humidity in the roasting process has a beneficial effect on bean properties (eg, improves the degree of sterilization of the material (Benz, 2002), color (Krysiak, 2006), or the fat content of cocoa (Krysiak and Motyl-Patelska, 2005). However, in the literature, there is a lack of information on how the increased humidity of air will affect the properties of the main ingredient of cocoa beans - namely cocoa butter.

Convection roasting of cocoa beans has a number of drawbacks. One of them is that due to the traditional way of heat and energy transfer, the heat treatment process takes too long. This may 
contribute to the loss of aroma, increased bitterness of beans and appearance of odor coming from the presence of for example acrolein (resulting from the disintegration of the glycerides in the fat) and certain other substances (e.g. dimethylpyrazine) which give an undesirable, burned flavor to the beans (Bednarski, 1986, Świechowski, 1996). The disadvantage of this method of roasting is also the existence of large temperature differences (from 10 to $12^{\circ} \mathrm{C}$ ) between the kernel and the husk of cocoa beans, which may contribute to the uneven process of roasting.

Another major disadvantage of convection roasting of the whole beans is a significant transfer of cocoa butter from kernel to husk. This phenomenon is very disadvantageous mainly due to economic reasons, since mass chocolate production uses only the kernel and the husk is waste. So, a greater fat content in the kernel of the bean will result in better properties of chocolate masses (Krysiak, and Motyl-Patelska, 2005, Nebesny and Rutkowski, 1998).

The above stated disadvantages of convection roasting of cocoa beans may also affect the properties of the fat that is the main component of cocoa beans. In the literature, information about the properties of cocoa butter obtained from cocoa beans of different types, coming from different regions of the world, or subjected to different processing operations can be found (fermentation, drying) (Chaiseri and Dimick, 1989, Foubert et al., 2004, Shamsuddin and Dimick, 1986, Shukla 1995), but data describing the properties of fat obtained from cocoa beans roasted in different conditions is scarce (Asep et al., 2008).

The application of microwaves seems to be an alternative method that can eliminate the disadvantages of convection roasting. The use of microwaves in the thermal processing of food can significantly shorten the process and the generation of a uniform heat creates conditions for more uniform temperature distribution in the material (Yoshida and Kajimoto, 1994).

The studies, which used microwaves in the process of roasting cocoa beans, were carried out in: Sweden (Faillon and Maloney, 1976), Switzerland (Swiss Pat 1985), Brazil (Fadini et al., 1997), Malaysia (Ing-STM 1990) among others. Research efforts taken in this area focused mainly on the technical possibilities of the application of microwaves to shorten process time and reduce the temperature of roasted beans, but they virtually ignored issues related to the properties of roasted beans, which are essential for the quality of the chocolate obtained. Only the works carried out by Eung-Jung Lee and coworker (Eung-Jung-Lee et al., 2000) or Fadini and coworker, (Fadini et al., 1997) relate to the effects of microwaves on the formation of flavor.

In the literature, the allegations against the microwave are that due to the heat generated inside the material, it is possible that unexpected chemical transformations will take place. In particular, it may influence products containing fats, including cocoa butter. Foods with a high fat and low water content quickly absorb microwaves and are intensely heated (Yoshida and Kajimoto, 1994). The rapid heating of products containing significant amounts of fat may be related to adverse factors, such as self-oxidation.

Based on numerous literature data (Albi et al., 1997, Farag, 1994, Farag et al., 1997, KołożynKrajewska, 1992, Tan et al., 2001, Yoshida and Kajimoto, 1994, Yoshida et al., 1995, Yoshida and Takagi, 1997) relating to the influence of microwave energy on fats in plant materials or extracted from them, it can concluded that the impact of this type of heat treatment is always negative. The observed discrepancies may result from applied microwave treatment parameters (time, temperature, power, frequency), but also with the kind of material undergoing the heating process, and whether the material was specially prepared previously (humidified, roasted, or having constituents that may affect the properties of fatty ingredients removed from it).

The presented work was undertaken due to the scarcity of studies devoted to the effects of different roasting methods (convective, microwave) on the physicochemical attributes of roasted cocoa beans and the quality of fat extracted from this material.

\section{MATERIALS AND METHODS}

Cocoa beans (the Ivory Coast variety) from the Ivory Coast were separated prior to roasting (Minifie, 1989) and only the medium size beans with a diameter of $18-24 \mathrm{~mm}$ were thermally processed.

\subsection{Cocoa bean roasting}

Cocoa beans were subjected to roasting in the following ways:

\section{Convective in the following conditions}

1. Air temperature $(\mathrm{T})$ of $135^{\circ} \mathrm{C}$, air flow rate $(\mathrm{v})$ of $1.0 \mathrm{~m} \times \mathrm{s}^{-1}$, relative humidity $(\mathrm{RH})$ of $0.4 \%$ ("dry air"), time (t) of $35 \mathrm{~min}$,

2. $\mathrm{T}$ of $135^{\circ} \mathrm{C}, \mathrm{v}$ of $1.0 \mathrm{~m} \times \mathrm{s}^{-1}, \mathrm{RH}$ of $5.0 \%$ ("humid air"), t of $45 \mathrm{~min}$,

3. $\mathrm{T}$ of $140^{\circ} \mathrm{C}$ and $\mathrm{RH}$ of $0.35 \%$ ("dry air"), at v of $0.5 \mathrm{~m} \times \mathrm{s}^{-1}$ for $10 \mathrm{~min}$, and at $\mathrm{v}$ of $1.0 \mathrm{~m} \times \mathrm{s}^{-1}$ for $20 \mathrm{~min}$ (an increase in air flow rate during heating).

The convection roasting of the beans was carried out in a tunnel with forced air flow and without recirculation. A detailed description of the equipment and methodology of measurements is given in (Krysiak and Motyl-Patelska, 2003).

\section{Microwave conditions} $\min$.

Power $\mathrm{M}=700 \mathrm{~W}, \mathrm{f}=2450 \mathrm{MHz}$, time $\mathrm{t}=12.5$ min.

The microwave roasting process was carried out in a Bosch microwave oven (Germany).

Regardless of the roasting method, a single heat treatment was applied to $200 \mathrm{~g}$ portions of beans distributed in a single layer. Roasting time was determined by the required $\sim 2 \%$ water content in the whole bean [Nebesny and Rutkowski, 1998]. 
During the convection roasting process the air parameters were controlled (temperature, flow rate and humidity). The temperature measurements of both air and kernel of cocoa beans were made using a YCY meter type YC-262 with an NiCr-NiAl (Taiwan) measuring probe. The air velocity was measured with a conjugated THERM 2285-2B meter with 9915 S120 by the Ahlborn's (Germany) measuring probe. Relative humidity of the "dry" air was calculated according to (Stobińska et al., 2006).

The increased air humidity $(\mathrm{RH}=5.0 \%)$ was obtained by placing saturated steam in the tunnel formed in the generator (Krysiak and Motyl-Patelska, 2005). Relative humidity was measured using a conjugated THERM 2285-2B meter with an FHA636HR2 by Ahlborn's (Germany) measuring probe.

The temperature in the microwave roasted bean kernel was determined immediately after the end of the process. The meter used was YCY type YC262 with an NiCr-NiAl measuring probe.

Roasted beans were air cooled to attain a temperature of $25^{\circ} \mathrm{C}$, and then stored at room temperature in sealed glass containers. Beans were shelled by hand and the kernel was crushed using a GM-1electric laboratory mill by ZBPP (Poland). In the fragmented bean (particle size $0,2-0,9 \mathrm{~mm}$ ): water and fat content, total and volatile acidity were determined, and cocoa butter was extracted. Extraction was carried out in the SoxtecTecator (Sweden) apparatus, according to the procedure recommended by the manufacturer for using chocolate as a substance, with petroleum ether (bp 40 to $60^{\circ} \mathrm{C}$ ) as the extracting substance.

\subsection{Determination of physicochemical properties}

\section{Cocoa bean analysis}

Water content of raw and roasted cocoa beans and of nibs and shells was determined according to the recommended procedure (Sandoval and Barreiro, 2002). Fat content in nibs was assayed according to the standard PN-A-88021:1971 (Krełowska-Kułas, 1993). Total acidity was estimated according to the standard PN-A-88024:1979 (Krełowska-Kułas, 1993) and volatile acidity according to Krełowska-Kułas (Krełowska-Kułas, 1993).

\section{Cocoa butter analysis}

Characteristic numbers (acid, saponification, iodine, peroxide) and the refractive index, defining the quality of fat were determined according to accepted standard methods. In addition, the softening temperature and total clarification of the solution temperature were determined (PN-A-88030:1998).

The viscosity of fats was determined with a Brookfield Engineering Laboratories Company INC type HADV III+ viscosimeter (USA). Measurements were performed at $40 \pm 0.5^{\circ} \mathrm{C}$ in the SC4-27 measurement vessel at a shear speed in the 5-60 $\mathrm{S}^{-1}$ range ( $\left.\mathrm{PN}-\mathrm{A}-88035: 1998\right)$.
The determination of hardness was performed using the penetrometric method with a Höpler penetrometer (Germany) and DSC 111 penetrometer by Setaram (France). The assay procedures used were published in the literature (Chaiseri and Dimick, 1989).

In addition, to determine the changes taking place in fats the following parameters were determined: amount and composition of the polar fraction, the degree of transformation in the fatty acids in the nonpolar fraction, the absorption of $1 \%\left(\mathrm{E}^{1 \%} \mathrm{~cm}\right)$ solution of the fat samples in hexane in UV light, and the absorption of $10 \%$ solution of the samples in hexane in visible light.

Determination of the amount and composition of the polar fraction was performed by column chromatography. The Kieselgel 60 (70-230 mesh) silica gel was used. The non-polar fraction was eluted with a petroleum ether: diethyl ether (87:13) mixture, and the polar fraction with diethyl ether. Determination was performed according to DGF Standard Methods, 1991, C-III 3b. The content of tri-, di- and monoacylglycerols and fatty acids in the polar fraction of various fats was tested by high performance size exclusion chromatography (HPSEC) according to the procedure by Pawłowicz and Drozdowski (Pawłowicz and Drozdowski 1997). The analysis was performed on a Variance 8500 chromatograph using a PLgel column with a length of $30 \mathrm{~cm}$ and $7.5 \mathrm{~mm}$ diameter, filled with polystyrene-divinylbenzene copolymer with a pore size of $500 \AA$ and grain diameter of $5 \mu \mathrm{m}$.

In order to determine the degree of transformation of fatty acids in cocoa butter (relative FA losses caused by heating) the fatty acid composition was determined in non-polar fractions, which contain thermooxidatively unchanged triacylglycerols. The fatty acid composition was determined by gas chromatography. For this purpose, the non-polar fraction was transformed into methyl esters in accordance with PN EN ISO 5509 (2000). The transesterification using $\mathrm{KOH}$ catalyst method was used. Determination was performed using a Pye Unicam PU 4550 gas chromatograph equipped with a flame-ionization detector (FID) and a stream splitter (90:1). For ester separation a capillary column with the symbol DB-23, 30m $\times 0.25 \mathrm{~mm}, 0.25 \mu \mathrm{m}(\mathrm{J}$ and $\mathrm{W}$ Sientific) was used. The temperature of the analysis was $180^{\circ} \mathrm{C}$. Injector and detector temperatures were $250^{\circ} \mathrm{C}$. The retention times and percentages of individual fatty acids were determined using a Hewlet Packard 3392A integrator.

Ther absorption of a $1 \%$ solution of the fat samples in hexane was measured for wavelengths of 233 and $270 \mathrm{~nm}$. Measurements were taken on a Genesis Milton Roy UV-VIS apparatus. The determination was based on the work of Tynek and Drozdowski (Tynek et al., 2001). Color change was measured by determining the absorption of a $10 \%$ $\left(\mathrm{E}^{10 \%} \mathrm{~cm}\right)$ sample solution in hexane, in visible light. The study was conducted at a wavelength of 420 $\mathrm{nm}$ (bandwidth for carotenes). Measurements were taken on a Genesis Milton Roy UV-VIS apparatus. The determination was based on the work of Mancini-Fiho et al. (Tynek et al., 2001). 
All evaluations were carried out in triplicate. The results were subjected to variance analysis (ANOVA) and the Duncan test (DMRT). Statistical significance of the results was determined at $p<0.05$.

\section{RESULTS AND DISCUSSION}

\subsection{Roasting of cocoa beans}

The selection of conditions such as roasting temperature, flow velocity, relative humidity and the type of energy was dependent on the following technological and process conditions:
A temperature of $130-150^{\circ} \mathrm{C}$ was chosen because of the type of cocoa beans (Ivory Coast) used in the studies and by the desired physical and chemical properties obtained after roasting.

Flow velocity was included in the study because of previous research conducted by Krysiak and coworkers (Krysiak et al., 2003), showing that this parameter significantly influences the speed of the roasting process and this in turn translates into quality of the roasted beans. However, the use of a variable flow rate in the roasting process resulted from the analysis of the roasting curves (Fig. 1) and the temperature roasting curves (Fig. 2) and the need

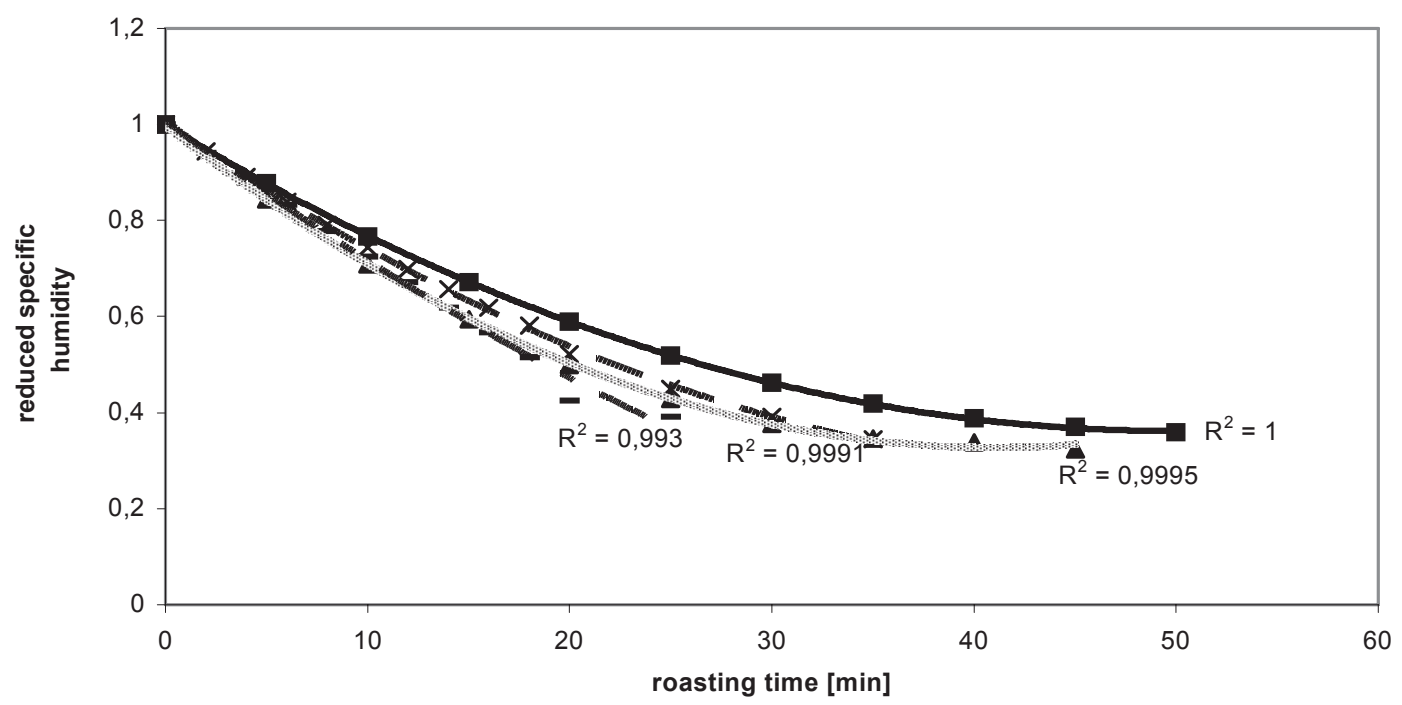

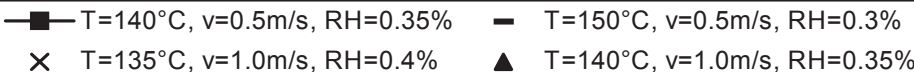

Figure 1

Effect of temperature and air flow rate on the reduced specific humidity* of cocoa beans during roasting in "dry" air *the reduced value of the specific air humidity was calculated by dividing of the current value of this quantity by its initial value
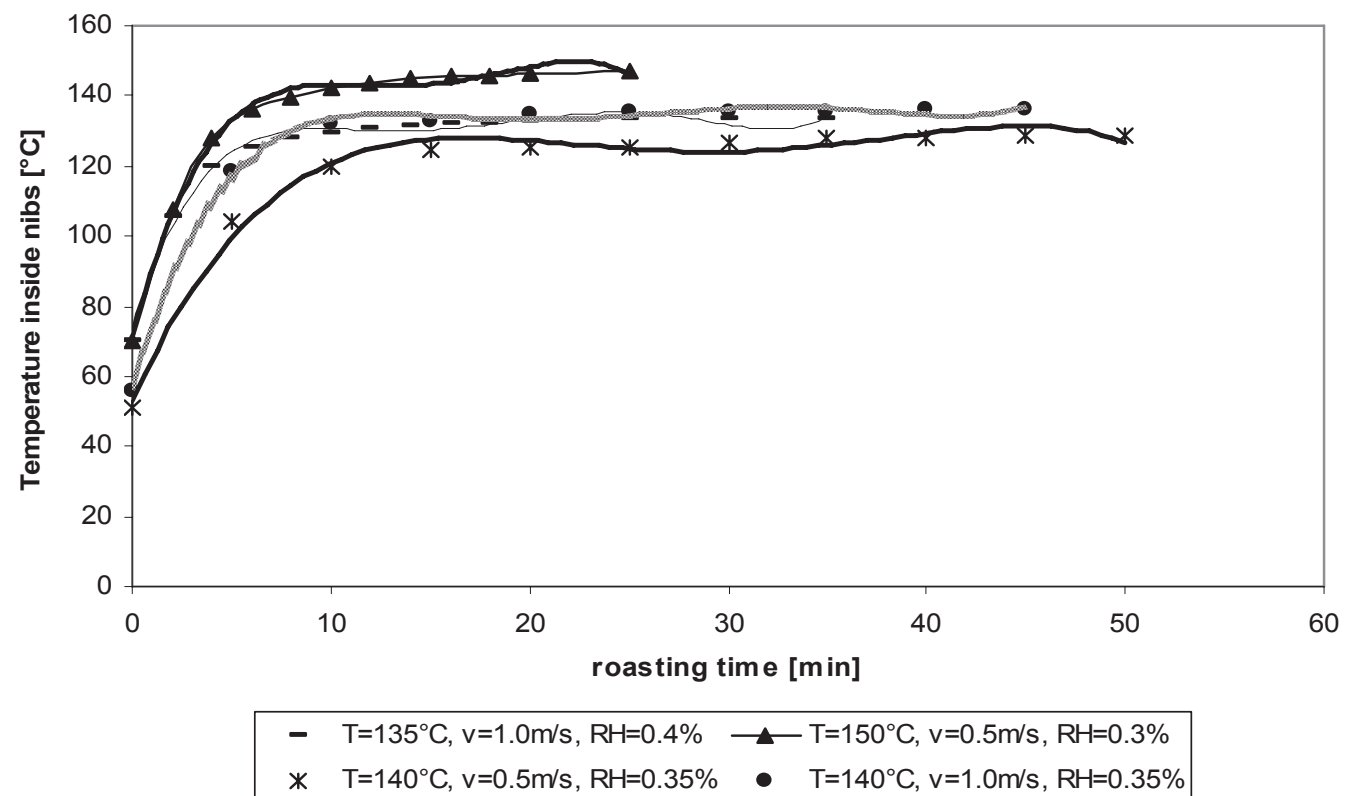

Figure 2

Changes in temperature inside cocoa nibs during roasting of cocoa beans in "dry" air 
to see how these conditions affect the properties of cocoa beans and the butter derived from them.

An analysis of the curves (Fig. 1 and 2) shows that the lowest temperature was achieved by beans roasted at $140^{\circ} \mathrm{C}$ at a flow velocity $\mathrm{v}=0.5 \mathrm{mxs} \mathrm{s}^{-1}$, while when the bean was roasted at $v=1.0$ $\mathrm{mxs}^{-1}$ the achieved temperature was virtually at similar levels regardless of which air temperature was used -135 or $140^{\circ} \mathrm{C}$. Taking that into consideration, the roasting conditions used were: air temperature $\mathrm{T}=140^{\circ} \mathrm{C}$, flow velocity $\mathrm{V}=$ $0.5 \mathrm{mxs}^{-1}$ for a time $\mathrm{t}=10 \mathrm{~min}$, and $\mathrm{v}=1.0 \mathrm{mxs}{ }^{-1}$, time $\mathrm{t}=20 \mathrm{~min}$, at a relative humidity $\mathrm{RH}=0.35 \%$.

The studies also included the impact of the third parameter, ie the relative air humidity, since the literature data indicates that the use of air with higher humidity promotes processes such as the sterilization of beans (Benz, 2002, Finken, 1996, Stobińska et al., 2006). This type of thermal processing results in products with better quality by reducing the possibility of oxidation reactions (Mujumdar, 1995).

Microwave heating was used because of the different way of generating heat in which the process is carried out at a high speed (Fadini et al., 1997, Mudgett, 1989). Furthermore, in previous studies (Stobińska et al., 2001) high microbiological purity was obtained for the cocoa beans roasted with microwaves. In the present work the method used consisted of microwave heating based on the continuous feeding of microwaves with a power of $700 \mathrm{~W}$ as a method able to achieve a water content of $2 \%$ in the kernel of the bean in a short period of time $(\mathrm{t}=12.5 \mathrm{~min})$ and a temperature similar to that noted for convection roasted beans in $\mathrm{T}=135^{\circ} \mathrm{C}$, flow velocity $v=1.0 \mathrm{~m} \mathrm{~s}^{-1}$, relative humidity $\mathrm{RH}=0.4 \%$, time t $=35$ min ("dry" air conditions).

\subsection{Influence of the roasting method on cocoa bean properties}

Table 1 shows the results of cocoa bean quality according to chosen methods, by convection and by microwaves. The inclusion of these results in this study was necessary due to the subsequent interpretation of the results of the analysis of cocoa butters extracted from the beans roasted by these methods. A detailed discussion of the effect of roasting conditions on the physicochemical properties of the roasted beans is present in earlier studies (Krysiak, 2002, Krysiak et al., 2003).

Summarizing the results of the analysis in Table 1 , it should be noted that among the proposed convection methods there is no single method that would clearly be beneficial in its influence on the desired characteristics of the bean (low total and volatile acidity, high fat content in the kernel). This is due to the specific composition of cocoa beans and the complex changes taking place during the roasting process. In terms of the greatest loss of total and volatile acidity in the methods, the best convective conditions seem to be $\mathrm{T}=135^{\circ} \mathrm{C}$, $\mathrm{v}=1.0 \mathrm{mxs}^{-1}$ at $\mathrm{RH}=0.4 \%$. These parameters of the process, however, cause too much transfer of fat from the kernel to the husk, at the level of $5.0 \%$, which is not desirable for technological and economic reasons. However, the greatest loss of this component from the kernel was observed when the beans roasted at $\mathrm{T}=140^{\circ} \mathrm{C}$, with variable air velocity and relative humidity $\mathrm{RH}=0.35 \%$. In this method comparatively high levels of total and volatile acidity were obtained, which is also not beneficial from the point of view of the technology. Research (Krysiak et al., 2003) shows that the roasting of cocoa beans at $150^{\circ} \mathrm{C}$, despite the shorter time, resulted in increased acidity of the roasted beans.

The application of air with higher humidity $(\mathrm{RH}=$ $5.0 \%$ ), despite contributing to reducing cocoa butter losses, resulted in a bean which was characterized by high total and volatile acidity.

The roasting of beans using microwaves allowed for a roasted bean with the most favorable physicochemical properties in a relatively short period of time, ie the lowest values of volatile and total acidity and the highest fat content. Such characteristics of the bean come from the fact that the heat was generated in a different way, and, consequently, for a short processing time.

Table 1

Selected physicochemical characteristics of cocoa beans roasted in different conditions

\begin{tabular}{ccccccc}
\hline $\begin{array}{c}\text { Roasting } \\
\text { process } \\
\text { conditions }\end{array}$ & \multicolumn{3}{c}{$\begin{array}{c}\text { Water content } \\
{[\%]}\end{array}$} & $\begin{array}{c}\text { Total acidity } \\
{\left[{ }^{\circ} \mathbf{n} / \mathbf{d} . \mathbf{m} . .\right]}\end{array}$ & $\begin{array}{c}\text { Volatile acidity } \\
{[\% \text { acetic acid/d.m.] }}\end{array}$ & $\begin{array}{c}\text { Fat content } \\
{[\% / d . m .]}\end{array}$ \\
\cline { 2 - 7 } & Whole bean & Kernel & Husk & Kernel & Kernel & Kernel \\
\hline Raw bean & $5.20 \pm 0.03$ & $4.55 \pm 0.05$ & $12.40 \pm 0.06$ & $14.59 \pm 0.7$ & $0.12 \pm 0.005$ & $59.04 \pm 0.08$ \\
CR1 & $2.01 \pm 0.02$ & $1.97 \pm 0.04$ & $4.94 \pm 0.06$ & $9.67 \pm 0.5$ & $0.07 \pm 0.003$ & $56.20 \pm 0.05$ \\
CR2 & $2.05 \pm 0.05$ & $1.75 \pm 0.03$ & $5.66 \pm 0.07$ & $14.22 \pm 0.6$ & $0.11 \pm 0.006$ & $57.69 \pm 0.04$ \\
CR3 & $1.97 \pm 007$ & $1.90 \pm 0.05$ & $4.91 \pm 0.07$ & $11.77 \pm 0.4$ & $0.08 \pm 0.003$ & $54.28 \pm 0.08$ \\
MR & $2.02 \pm 0.06$ & $1.78 \pm 0.02$ & $5.76 \pm 0.4$ & $7.79 \pm 0.7$ & $0.05 \pm 0.006$ & $58.3 \pm 0.05$ \\
\hline
\end{tabular}

CR1 - convectively roasted bean $\mathrm{T}=135^{\circ} \mathrm{C}, \mathrm{v}=1,0 \mathrm{~m} \mathrm{~s}^{-1}, \mathrm{RH}=0,4 \%, \mathrm{t}=35 \mathrm{~min}$

CR2 - convectively roasted bean $\mathrm{T}=135^{\circ} \mathrm{C}, \mathrm{v}=1,0 \mathrm{~m} \mathrm{~s}^{-1}, \mathrm{RH}=5,0 \%, \mathrm{t}=60 \mathrm{~min}$

CR3 - convectively roasted bean $T=140^{\circ} \mathrm{C}, v=0,5 \mathrm{~m} \mathrm{~s}^{-1}, \mathrm{RH}=0,35 \%, t=10 \mathrm{~min}+\mathrm{T}=140^{\circ} \mathrm{C}, \mathrm{v}=1,0 \mathrm{~m} \mathrm{~s}^{-1}, \mathrm{RH}=0,35 \%, t=20 \mathrm{~min}$

$\mathrm{MR}-$ microwave roasted bean $\mathrm{M}=700 \mathrm{~W}, \mathrm{t}=12,5 \mathrm{~min}$ 


\subsection{Influence of the roasting methods on cocoa butter properties}

Table 2 summarizes the results of the main physicochemical properties of cocoa butters extracted from the kernels of raw and roasted cocoa beans using convection and microwave methods.

The obtained values of the basic quality parameters of cocoa fat in most cases are within the limits laid down in the standards. According to the (PN-A-88113: 1998) standard and the literature (Chaiseri and Dimick, 1989, Shukla 1995) the free fatty acid content (FFA) expressed as \% of oleic acid is $0,5-3,1$; IV $=193.3-$ $194.2 \mathrm{~g} \mathrm{I}_{2} / 100 \mathrm{~g} ; \mathrm{SV}=188-198 \mathrm{mgKOH} / \mathrm{g}$, refraction index $n_{D}^{40}(1,456-1,459)$ and a softening temperature $\left(T_{\mathrm{s}}=29\right.$ to $\left.33^{\circ} \mathrm{C}\right)$ and the clarification temperature $\left(T_{\mathrm{c}}\right.$ $=30$ to $34^{\circ} \mathrm{C}$ ). The obtained values show that only the saponification value (SV) can be regarded as too low, especially in the case of roasting beans in $\mathrm{T}=135^{\circ} \mathrm{C}, \mathrm{v}$ $=1.0 \mathrm{mxs}^{-1}, \mathrm{RH}=5.0 \%, \mathrm{t}=60 \mathrm{~min}$. and in microwave roasting. In the first case it may be due to the long time in the air with higher humidity $(\mathrm{RH}=5.0 \%)$ and achieving a kernel with a higher temperature than in the case of the process carried out in "dry" air at the same temperature (Fig. 3).

In the case of the application of microwaves these changes may be dictated by the higher temperature in the kernel of the bean due to the different way of heating the material (Albi et al., 1997). Lowering of the SV value probably comes from the degradation of triacylglycerols and changes in free fatty acids. Also, Yoshida et al. (Yoshida et al., 1995) found that the triacylglycerols present in sesame oil obtained from microwave roasted sesame seeds were slightly hydrolyzed in random locations. A lowering of the level of free fatty acids with increasing temperature was observed by Ozdemir and coworkers (Ozdemir et al., 2001). According to them, this phenomenon may be due to the reduced activity of hydrolytic enzymes such as lipase and peroxidase.

However it should be noted that the observed changes in SV are no greater than $0.5 \%$ when compared to the minimum values given by the PN-A-88113:1998 standard and other literature data (Chaiseri and Dimick, 1989, Shukla, 1995).

The IVs of the analyzed fats are within 29.4-37.0 $\mathrm{g} \mathrm{I}_{2} / 100 \mathrm{~g}$ fat. The lowest IV values $(29.4$ and $31.9 \mathrm{~g}$ $\mathrm{I}_{2} / \mathrm{kg}$ ), which are well below the value given by the PN-A-88113:1998 standard and the literature data (Chaiseri and Dimick, 1989, Shukla 1995), were the characteristics of the fat from beans subject to the microwave roasting method and raw beans. For the other cocoa butters, the values were within the range of $34,6-37,02 \mathrm{~g} \mathrm{I}_{2} / 100 \mathrm{~g}$, thus the values were consistent with the cited literature references (Chaiseri and Dimick, 1989, Shukla, 1995, PN-A-88113:1998).

IV is a convenient indicator of the degree of hardness of cocoa butter. Higher values of IV of cocoa butter $\left(35,4-37,0 \mathrm{~g} \mathrm{I}_{2} / 100 \mathrm{~g}\right)$ indicate a higher content of unsaturated fatty acids included in the triacylglycerols. In the case of cocoa butter, these acids are responsible for most of its softness (Chaiseri and Dimick, 1989). This is confirmed by the hardness results obtained by the penetrometer measurements shown in Table 2. The only exception is the lack of correlation between the IV and the hardness of fat obtained from the microwave roasted beans. In this case the lowest IV values and the highest values of hardness were observed. This may be due to the generation of high temperatures within the heated material in a short time, which causes unforeseen changes in the fatty acids included in the triacylglycerols. Similar relationships were observed by Albi and coworkers (Albi et al., 1997) during the microwave heating of vegetable oil.

Table 2

Physicochemical characteristics of fat extracted from cocoa beans roasted in different conditions

\begin{tabular}{cccccc}
\hline Determined factor & \multicolumn{5}{c}{ Source of fat } \\
\cline { 2 - 6 } & $\mathbf{( 1 )}$ & $\mathbf{( 2 )}$ & $\mathbf{( 3 )}$ & $\mathbf{( 4 )}$ & $\mathbf{( 5 )}$ \\
\hline FFA [\% oleic acid] & $0.99 \pm 0.04$ & $1.06 \pm 0.05$ & $1.07 \pm 0.04$ & $1.00 \pm 0.06$ & $1.10 \pm 0.07$ \\
$\mathrm{SV}[\mathrm{mgKOH} / \mathrm{g}]$ & $187.0 \pm 0.5$ & $192.6 \pm 1.05$ & $182.3 \pm 1.10$ & $187.0 \pm 1.01$ & $183.1 \pm 0.95$ \\
$\mathrm{PV}\left[\mathrm{mmol} \mathrm{O}_{2} / \mathrm{kg}\right]$ & $1.3 \pm 0.05$ & $2.1 \pm 0.10$ & $2.3 \pm 0.07$ & $1.4 \pm 0.05$ & $2.0 \pm 0.09$ \\
$\mathrm{IV}\left[\mathrm{g} \mathrm{I}_{2} / 100 \mathrm{~g}\right]$ & $31.9 \pm 0.9$ & $34.6 \pm 0.6$ & $35.7 \pm 0.5$ & $37.0 \pm 0.7$ & $29.4 \pm 1.5$ \\
$\mathrm{n}_{\mathrm{D}}{ }^{40}$ & $1.457 \pm 0.0005$ & $1.457 \pm 0.0005$ & $1.456 \pm 0.0005$ & $1.458 \pm 0.0005$ & $1.455 \pm 0.0005$ \\
Hardness $\left[{ }^{\circ} \mathrm{p}\right]$ & $0.25 \pm 0.005$ & $0.46 \pm 0.005$ & $0.48 \pm 0.005$ & $0.61 \pm 0.005$ & $0.62 \pm 0.005$ \\
Viscosity $[\mathrm{mPa} \mathrm{s}]$ & $25.5 \pm 0.5$ & $39.49 \pm 0.5$ & $32.95 \pm 0.5$ & $34.00 \pm 0.5$ & $38.0 \pm 0.5$ \\
Softening point $\left[{ }^{\circ} \mathrm{C}\right]$ & $27.7 \pm 0.5$ & $31.5 \pm 0.5$ & $30.1 \pm 0.5$ & $30.5 \pm 0.5$ & $31.8 \pm 0.5$ \\
Clarification point $\left[{ }^{\circ} \mathrm{C}\right]$ & $33.5 \pm 0.5$ & $32.9 \pm 0.5$ & $33.1 \pm 0.5$ & $31.9 \pm 0.5$ & $33.4 \pm 0.5$ \\
\hline
\end{tabular}

(1) - cocoa butter extracted from raw bean kernel

(2) - cocoa butter extracted from convectively roasted bean kernel $\mathrm{T}=135^{\circ} \mathrm{C}, \mathrm{v}=1,0 \mathrm{~m} \mathrm{~s}^{-1}, \mathrm{RH}=0,4 \%, \mathrm{t}=35 \mathrm{~min}$

(3) - cocoa butter extracted from convectively roasted bean kernel $\mathrm{T}=135^{\circ} \mathrm{C}, \mathrm{v}=1,0 \mathrm{~m} \mathrm{~s}^{-1}, \mathrm{RH}=5,0 \%, \mathrm{t}=60 \mathrm{~min}$

(4) - cocoa butter extracted from convectively roasted bean kernel $\mathrm{T}=140^{\circ} \mathrm{C}, \mathrm{v}=0,5 \mathrm{~m} \mathrm{~s}{ }^{-1}, \mathrm{RH}=0,35 \%, \mathrm{t}=10 \mathrm{~min}+\mathrm{T}=140^{\circ} \mathrm{C}, \mathrm{v}=1,0 \mathrm{~m}$

$\mathrm{s}^{-1}, \mathrm{RH}=0,35 \%, \mathrm{t}=20 \mathrm{~min}$

(5) - cocoa butter extracted from microwave roasted bean kernel $\mathrm{M}=700 \mathrm{~W}, \mathrm{t}=12,5 \mathrm{~min}$ 


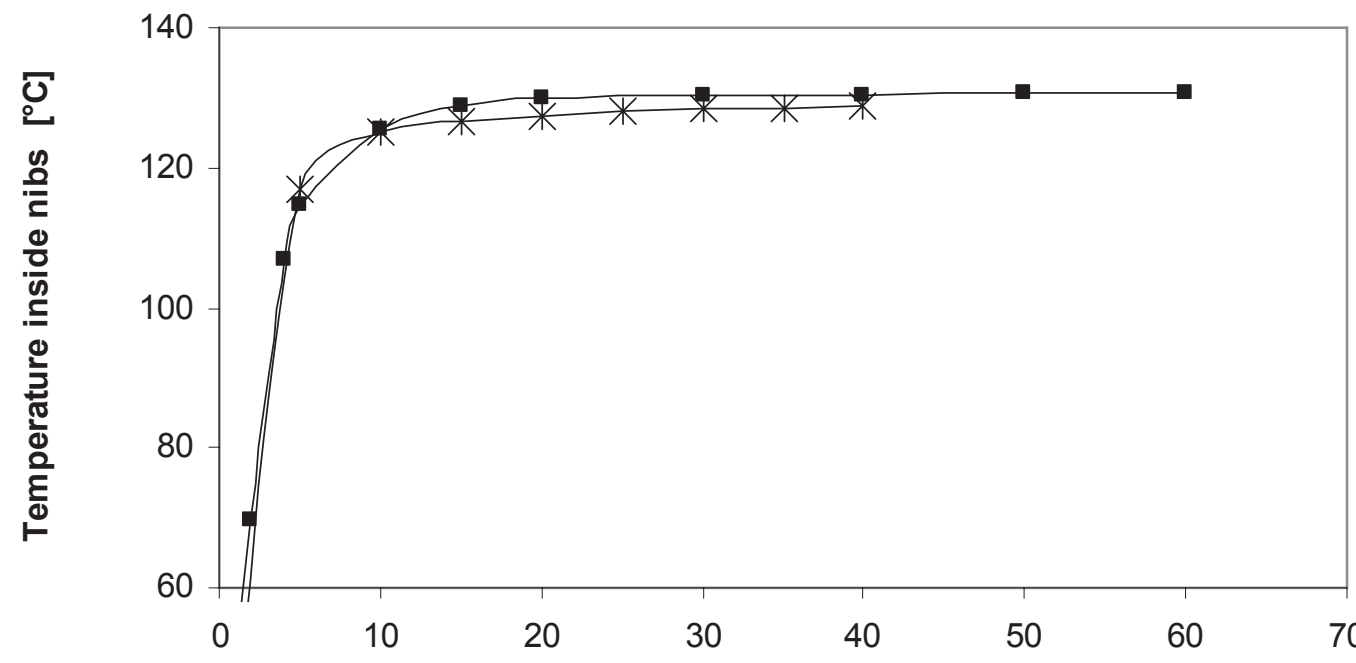

Roasting time [min]

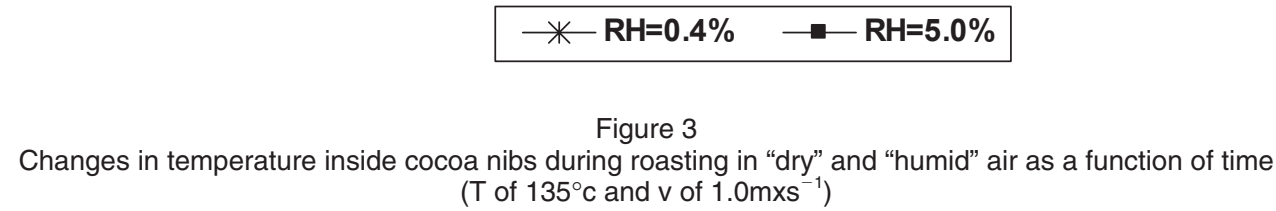

However, given the statistical evaluation of the results it is concluded that the method of roasting has a significant impact on the IV.

The peroxide values were determined to be in the 1.3-2.3 $\mathrm{mmol} \mathrm{O}_{2} / \mathrm{kg}$ fat range.

Together with Tan and coworkers [Tan et al., 2001] many researchers believe that the PV level above $3.5 \mathrm{mmol} \mathrm{O}_{2} / \mathrm{kg}$ fat is an unsatisfactory level due to its sensory properties.

The lowest PV was the characteristics of fat extracted from raw cocoa beans (1) (Table 1). Oomah and coworkers (Oomah et al., 1998) determined a lower PV in the fat from unprocessed grape seeds than in fat from seeds subjected to a thermal treatment.

The process of roasting increased the PV. To the lowest degree, only slightly over $7 \%$ (PV $=1.4 \mathrm{mmol}$ $\mathrm{O}_{2} / \mathrm{kg}$ fat) the increase of this value was observed for cocoa butter (4) (Table 2) that was extracted from beans roasted by convection at $\mathrm{T}=140^{\circ} \mathrm{C}$, but with the use of variable air flow velocity. Such a change in the PV may be due to the milder conditions used in roasting time up to 10 minutes (Fig. 2) and overall shorter $(t=30$ min) time of the heating medium operation. It may also be the antioxidant effects of products formed during the heating of biological material, e.g. as a result of the Maillard reaction (Tynek et al., 2001) For other variants of roasting the PV was found to be in the range of 2,0$2,3 \mathrm{mmol} \mathrm{O} / \mathrm{kg}$ fat. The relatively low value of PV (PV $=2.0 \mathrm{mmol} \mathrm{O} / \mathrm{kg}$ fat) for cocoa butter extracted from microwave roasted beans can be caused by a different method of heating the bean, short process time $(t=$ $12.5 \mathrm{~min}$ ), and similarly as in roasting at $\mathrm{T}=140^{\circ} \mathrm{C}$, the presence of antioxidant substances in the cocoa butter. Tan and coworkers (Tan et al., 2001) believe that the reasons for low values of PV in soy and corn oils heated by microwave for up to 12 minutes time can be found in the formation of hydroxyperoxides at lower temperatures. However, longer heating increases the temperature, which contributes to the rapid decomposition of the hydroxyperoxides to secondary, labile products, which can transform into products such as alcohols, aldehydes, ketones, acids, dimers, trimers, polymers and cyclic compounds. This may be confirmed by the result of the adsorption of $1 \%$ solution of samples in hexane (Table 5).

The least favorable in terms of obtaining the highest PV of cocoa butter was the method of convection roasting of beans in air with higher humidity $(\mathrm{RH}=5.0 \%)$. Such properties of fat may be due to a long time ( $t=60 \mathrm{~min})$ of $\mathrm{T}=135^{\circ} \mathrm{C}$ temperature operation, but also the influence of moisture contained in the air heating the bean. Yoshida and coworkers (Yoshida et al., 1995) showed that the fat properties may depend on the moisture content contained in it. Increased water content in the material subjected then to thermal treatment contributes to the formation of smaller quantities of bronze substances, which significantly influence the nature of oxidative changes in fat.

In the case of the FFA content the lowest value (FFA $=0.99 \%)$ is the characteristics of fat from raw beans, while the FFA content of fats extracted from beans roasted by various methods was determined to be within the limits of $1,06-1,10 \%$. In the case of beans roasted by convection (cocoa butters 2, 3 and 4) (Table 2) the values of FFA were respectively 1.06 , 1.07 and $1.0 \%$. Higher FFA values when compared to fat from raw beans can be associated with organic acids remaining in the kernel of cocoa beans, which are then passed to the extracted fat (Table 1).

The highest values of FFA $=1.10 \%$ were observed for cocoa butter (5) (Table 2) meaning the 
beans roasted by microwaves. Similar relationships in their research were found by Albi and coworkers (Albi et al., 1997) and Yoshida (Yoshida et al, 1995).

No significant changes in the values of the refractive index $\left(n_{D}^{40}=1.455 \div 1.458\right)$ were found in the cocoa butter obtained from roasted beans in relation to the fat extracted from raw beans. The lowest observed $n^{40}$ values (1.455) for the fat extracted from beans heated by microwaves can be attributed to the generation of relatively high temperatures in the product within a short time.

The viscosity of fats extracted from heat-treated beans increases significantly, almost doubles, in relation to the viscosity of crude fat from beans. No significant differences in viscosity values between bean roasting methods were found. Similar relationships were observed by Albi and coworker (Albi et al., 1997) and Oomah and coworker (Oomah et al., 1998). The increase in the value of this quality parameter of fat may be linked to the formation of dimers or polymers as a result of lengthening the carbon chains (Albi et al., 1997) or as differences in saturation of fatty acids (Oomah et al. 1998). This, in turn, may translate into higher softening point temperatures, as observed in the analyzed cocoa butter (Table 2). However, the temperature readout based on the conducted thermographic studies (DSC) showed no significant differences between the fat obtained from raw beans and beans roasted by microwaves (Fig. 4). Also Chaiseri and Dimick. (Chaiseri and Dimick, 1989) have not acquired a good correlation between the hardness determined by penetrometer and by DSC.

The obtained results have not allowed to explicitly specify the influence of roasting method on the actual changes occurring in the cocoa butter contained in cocoa beans. Therefore, to estimate changes in the extracted cocoa butters the content of polar fraction, composition of the polar fraction, and the degree of transformation of fatty acids in the non-polar fraction were determined.

\section{Determination of amount and composition of the polar fraction}

The amount and composition of the polar fraction of cocoa butter extracted from the kernels of cocoa beans roasted by various methods is shown in Table 3 .

The determinations show that the polar fraction content in relation to starting fat increased slightly due to heating. Taking into account the statistical evaluation of the results, differences are not found in the content of the polar fraction between trials 2 , 3 , 4. The fat (5) contains about $1 \%$ more of this fraction than other fats, which means that the fat has undergone the biggest changes, in relation to the other samples. Polar fraction in accordance with the

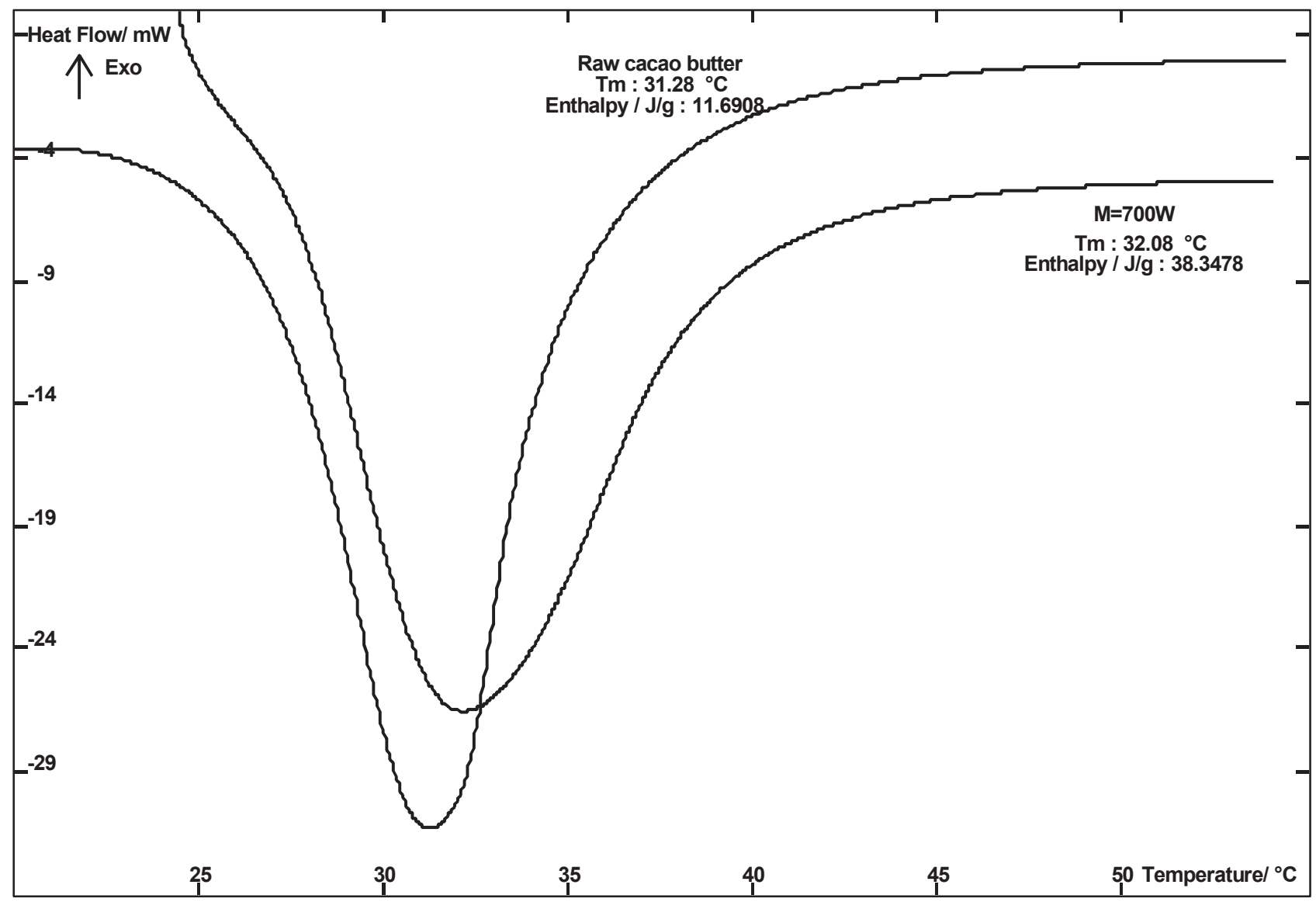

Figure 4

DSC thermograms of fat extracted from raw and microwave heated cocoa beans 
Table 3

Composition of polar fraction of fat extracted from cocoa beans roasted in different conditions

\begin{tabular}{ccccccc}
\hline Source of & Polar fraction & \multicolumn{5}{c}{ Polar fraction composition [\%] } \\
\cline { 3 - 6 } cocoa butter & amount [\%] & TAG dimers & oxidated TAG & DAG & MAG & FA \\
\hline$(\mathbf{1})$ & $3.0 \pm 0.2$ & $0.00 \pm 0.00$ & $1.54 \pm 0.08$ & $1.02 \pm 0.01$ & $0.03 \pm 0.01$ & $0.41 \pm 0.01$ \\
$(\mathbf{2})$ & $4.0 \pm 0.3$ & $0.04 \pm 0.01$ & $1.77 \pm 0.12$ & $1.17 \pm 0.03$ & $0.03 \pm 0.01$ & $1.00 \pm 0.07$ \\
$(\mathbf{3})$ & $4.3 \pm 0.1$ & $0.00 \pm 0.00$ & $1.83 \pm 0.11$ & $1.35 \pm 0.01$ & $0.02 \pm 0.01$ & $1.09 \pm 0.05$ \\
$(\mathbf{4})$ & $4.2 \pm 0.2$ & $0.04 \pm 0.01$ & $2.08 \pm 0.15$ & $1.48 \pm 0.06$ & $0.03 \pm 001$ & $0.57 \pm 0.01$ \\
$(\mathbf{5})$ & $5.5 \pm 0.1$ & $0.00 \pm 0.00$ & $2.39 \pm 0.23$ & $1.73 \pm 0.11$ & $0.03 \pm 0.01$ & $1.35 \pm 0.10$ \\
\hline
\end{tabular}

(1) - cocoa butter extracted from raw bean kernel

(2) - cocoa butter extracted from convectively roasted bean kernel $\mathrm{T}=135^{\circ} \mathrm{C}, \mathrm{v}=1,0 \mathrm{~m} \mathrm{~s} \mathrm{~s}^{-1}, \mathrm{RH}=0,4 \%, \mathrm{t}=35 \mathrm{~min}$

(3) - cocoa butter extracted from convectively roasted bean kernel $\mathrm{T}=135^{\circ} \mathrm{C}, \mathrm{v}=1,0 \mathrm{~m} \mathrm{~s}^{-1}, \mathrm{RH}=5,0 \%, \mathrm{t}=60 \mathrm{~min}$

(4) - cocoa butter extracted from convectively roasted bean kernel $\mathrm{T}=140^{\circ} \mathrm{C}, \mathrm{v}=0,5 \mathrm{~m} \mathrm{~s}{ }^{-1}, \mathrm{RH}=0,35 \%, \mathrm{t}=10 \mathrm{~min}+\mathrm{T}=140^{\circ} \mathrm{C}, \mathrm{v}=1,0 \mathrm{~m}$

$\mathrm{s}^{-1}, \mathrm{RH}=0,35 \%, \mathrm{t}=20 \mathrm{~min}$

(5) - cocoa butter extracted from microwave roasted bean kernel $\mathrm{M}=700 \mathrm{~W}, \mathrm{t}=12,5 \mathrm{~min}$

legislation in the European Union is the determinant of thermooxidative transformations of fats. For example, edible, commercially available refined oils contain the polar fraction at a level of $3-4 \%$, while frying fat is withdrawn from circulation (fried food bars) after exceeding the polar fraction content of $25-27 \%$. Based on this data it is clear that the majority of the analyzed fat only slightly exceeds the level of $4 \%$.

Slight differences were noted in the composition of the polar fraction of the examined fats. Prioritizing according to the rule: from the largest to the smallest degree of change, the tested fats can be categorized according to the following sequence:

For TAG dimmer content $4=2>1,4$ and 5 no dimers,

For oxidated TAG content........ $>4>3>2>1$,

For DAG content ................. $>4>3>2>1$,

For MAG content ................. $5=4=1=2=3$,

For FA content ........................... $5>3 \approx 2>4>1$

An analysis of individual components shows that the greatest changes took place in fat (5) obtained from the beans roasted by the continuous microwaving method, although not even trace amounts of dimers were found in it. The amount of diacylglycerols (DAG) describes the degree of hydrolysis. Therefore, the degree of hydrolysis of the tested fats is sorted in the order described above for the DAG fraction. It should be noted, however, that like in the work of Conssignani and coworkers (Conssignani et al., 1998) the quantity of polar fraction and content of its individual components in the samples is small and close to the values found in raw fat. In this list the worst properties are shown for the fat from microwave roasted beans.

\section{Determination of the progress of fatty acid transformations}

In order to determine the degree of transformation of fatty acids in the heated samples of cocoa butter, the fatty acid composition was determined in the non-polar fraction, which contains thermooxidatively unchanged triacylglycerols. As shown by the data presented in Table 4, in the tested fats, taking into account the losses of FA, generally speaking thermooxidative changes are at a very low level. These changes influenced mainly polyene acids (the loss of C18:2 is $11,1-13,4 \%$ for fat samples 3 and 5, while the loss of C18:3, 51.9 and $55.6 \%$ respectively). However, given the starting low levels of these acids in the raw material subjected to thermal treatment these changes do not significantly affect the quality factors of the tested fat. Similar relationships were observed by Conssignani and coworkers (Conssignani et al., 1998).

Higher amounts of palmitic acid determined in the heated fat samples is assumed to be a natural phenomenon, due to the fact that fats containing shorter chain acids hydrolyze easier than the ones containing longer chains. This is confirmed by experiments by Farag and coworkers (Farag et al., 1997) who determined varying (increasing or decreasing) amounts of palmitic acid using microwave heated olive oil when compared to samples not subject to heating.

\section{Determination of the absorption level of $1 \%$ and $10 \%$ solution of fat samples in hexane}

Changes in the absorption of $1 \%$ solutions of analyzed samples of fat $\left(E^{1 \%}{ }_{1 \mathrm{~cm}}\right)$ at $\lambda=233$ and $270 \mathrm{~nm}$ determine the content of secondary oxidation products in fats, especially those containing aldehydes and ketones (Tynek et al., 2001). Data contained in Table 5 indicate relatively small changes, which confirm previous conclusions on changes in fatty acids in the tested samples subjected to heating. However, most oxidation products were observed in the sample of fat (4), meaning fat obtained from beans treated with convective heating at the highest of the proposed temperatures.

In this respect the most preferred method seems to be the roasting of beans in the air with higher relative humidity. It is associated with the demonstrated lower oxidation of products heated in humid air. Water vapor in air forms a protective 
Table 4

Fatty acid composition of fat extracted from cocoa beans roasted in different conditions

\begin{tabular}{|c|c|c|c|c|c|}
\hline \multirow{2}{*}{ Fatty acid } & (1) & (2) & (3) & (4) & (5) \\
\hline & \multicolumn{5}{|c|}{ FA content [\%] } \\
\hline $14: 0$ & 0.12 & 0.09 & 0.10 & 0.09 & 0.09 \\
\hline $15: 0$ & 0.02 & 0.03 & 0.03 & 0.03 & 0.02 \\
\hline $16: 0$ & 24.37 & 24.59 & 23.13 & 24.56 & 24.18 \\
\hline $16: 1(9 c)$ & 0.25 & 0.23 & 0.22 & 0.22 & 0.22 \\
\hline $17: 0$ & 0.22 & 0.22 & 0.22 & 0.21 & 0.21 \\
\hline $17: 1$ & 0.02 & 0.02 & 0.01 & 0.03 & 0.01 \\
\hline $18: 0$ & 33.85 & 34.04 & 33.59 & 33.82 & 33.51 \\
\hline $18: 1(9 c)$ & 33.50 & 32.56 & 32.31 & 32.67 & 32.25 \\
\hline $18: 2(9 c, 12 c)$ & 3.06 & 2.76 & 2.72 & 2.77 & 2.65 \\
\hline $18: 3(9 t, 12 t, 15 t)$ & 0.02 & 0.02 & 0.02 & 0.02 & 0.01 \\
\hline $18: 3(9 c, 12 c, 15 c)$ & 0.27 & 0.15 & 0.12 & 0.15 & 0.11 \\
\hline $20: 0$ & 0.93 & 0.95 & 0.93 & 0.96 & 0.95 \\
\hline $20: 1(9 c)$ & 0.06 & 0.05 & 0.05 & 0.07 & 0.05 \\
\hline $21: 0$ & 0.03 & 0.01 & 0.01 & 0.03 & 0.02 \\
\hline $22: 0$ & 0.19 & 0.18 & 0.16 & 0.17 & 0.17 \\
\hline Other FA & 0.08 & 0.04 & 0.06 & 0.01 & 0.05 \\
\hline
\end{tabular}

(1) - cocoa butter extracted from raw bean kernel

(2) - cocoa butter extracted from convectively roasted bean kernel $\mathrm{T}=135^{\circ} \mathrm{C}, \mathrm{v}=1,0 \mathrm{~m} \mathrm{~s}{ }^{-1}, \mathrm{RH}=0,4 \%, \mathrm{t}=35 \mathrm{~min}$

(3) - cocoa butter extracted from convectively roasted bean kernel $\mathrm{T}=135^{\circ} \mathrm{C}, \mathrm{v}=1,0 \mathrm{~m} \mathrm{~s}^{-1}, \mathrm{RH}=5,0 \%, \mathrm{t}=60 \mathrm{~min}$

(4) - cocoa butter extracted from convectively roasted bean kernel $\mathrm{T}=140^{\circ} \mathrm{C}, \mathrm{v}=0,5 \mathrm{~m} \mathrm{~s}^{-1}, \mathrm{RH}=0,35 \%, \mathrm{t}=10 \mathrm{~min}+\mathrm{T}=140^{\circ} \mathrm{C}, \mathrm{v}=1,0 \mathrm{~m}$

$\mathrm{s}^{-1}, \mathrm{RH}=0,35 \%, \mathrm{t}=20 \mathrm{~min}$

(5) - cocoa butter extracted from microwave roasted bean kernel $\mathrm{M}=700 \mathrm{~W}, \mathrm{t}=12,5 \mathrm{~min}$

Table 5

Absorbance of $1 \%$ and $10 \%$ hexane solutions of fat extracted from cocoa beans roasted in different conditions

\begin{tabular}{|c|c|c|c|}
\hline \multirow{2}{*}{ Source of cocoa butter } & \multicolumn{2}{|c|}{ Absorption of $1 \%$ butter sample at } & \multirow{2}{*}{$\begin{array}{c}\text { Absorption of } 10 \% \\
\text { butter sample at } \\
\lambda 420 \mathrm{~nm}\left[\mathrm{E}^{10 \%}{ }_{420}\right]\end{array}$} \\
\hline & $\lambda 233 \mathrm{~nm}\left[\mathrm{E}_{233}^{1 \%}\right]$ & $\lambda$ 270nm $\left[E_{270}^{1 \%}\right]$ & \\
\hline (1) & $1.230( \pm 0.050)$ & 0.01 no maximum & $0.141( \pm 0.013)$ \\
\hline (2) & $1.401( \pm 0.132)$ & $0.246( \pm 0.016)$ & $0.225( \pm 0.026)$ \\
\hline (3) & $1.257( \pm 0.016)$ & $0.222( \pm 0.013)$ & $0.122( \pm 0.001)$ \\
\hline (4) & $1.433( \pm 0.088)$ & $0.354( \pm 0.013)$ & $0.164( \pm 0.001)$ \\
\hline (5) & $1.280( \pm 0.065)$ & $0.255( \pm 0.053)$ & $0.220( \pm 0.015)$ \\
\hline
\end{tabular}

(1) - cocoa butter extracted from raw bean kernel

(2) - cocoa butter extracted from convectively roasted bean kernel $\mathrm{T}=135^{\circ} \mathrm{C}, \mathrm{v}=1,0 \mathrm{~m} \mathrm{~s}^{-1}, \mathrm{RH}=0,4 \%, \mathrm{t}=35 \mathrm{~min}$

(3) - cocoa butter extracted from convectively roasted bean kernel $\mathrm{T}=135^{\circ} \mathrm{C}, \mathrm{v}=1,0 \mathrm{~m} \mathrm{~s}^{-1}, \mathrm{RH}=5,0 \%, \mathrm{t}=60 \mathrm{~min}$

(4) - cocoa butter extracted from convectively roasted bean kernel $\mathrm{T}=140^{\circ} \mathrm{C}, \mathrm{v}=0,5 \mathrm{~m} \mathrm{~s}{ }^{-1}, \mathrm{RH}=0,35 \%, \mathrm{t}=10 \mathrm{~min}+\mathrm{T}=140^{\circ} \mathrm{C}, \mathrm{v}=1,0 \mathrm{~m}$

$\mathrm{s}^{-1}, \mathrm{RH}=0,35 \%, \mathrm{t}=20 \mathrm{~min}$

(5) - cocoa butter extracted from microwave roasted bean kernel $\mathrm{M}=700 \mathrm{~W}, \mathrm{t}=12,5 \mathrm{~min}$

layer that prevents the penetration of oxygen (Mujumdar, 1995, Tynek et al., 2001).

Also Albi and coworkers (Albi et al., 1997) in their studies on vegetable oils heated by convection and microwave methods obtained an increase in $\left(E_{1 \%}{ }^{1 \mathrm{~cm}}\right)$ value at $\lambda=233$ and $270 \mathrm{~nm}$.
The obtained results do not show a good correlation with the results of PV (Table 2). Thus, this indicates the need for additional determinations of factors in fats because the PV cannot be the sole criterion for determining the degree of changes in fat, as suggested by some researchers (Tynek et al., 2001). 
The determined changes in color $\left(E_{10 \%}{ }^{11 m}\right)$ of the fat samples indicate that in each case of fat heating there was a reduction in carotinoids, the lowest for sample (3). This characteristic change in color indicates the positive effect of moisture contained in air with higher humidity on slowing the reaction of the formation of brown products. Similar relationships were obtained by Yoshida and coworkers (Yoshida et al., 1995) and Yoshida and Takagi (Yoshida and Takagi 1997) for the microwave heating of soy beans and sesame seeds.

For fat (2) and (5) an increase in the value of $\left(\mathrm{E}_{1 \%}{ }^{1 \mathrm{~cm}}\right)$ indicator was seen, which is related to the rate of removing water from beans and the strong influence of the Maillard reaction on the magnitude of this parameter (Tynek et al., 2001).

\section{CONCLUSIONS}

The present results show that microwaves favorably affected the physicochemical properties of cocoa beans. After a time of $12.5 \mathrm{~min}$ the largest reduction in the total and volatile acidity of the beans was obtained, and fat has migrated from the kernel to the husk in the lowest degree. However, the fat extracted from the beans roasted this way underwent the greatest changes. This is indicated by the fundamental values of indicators of the quality of fat (FFA, PV, IV, melting point), and by detailed analyses such as the amount and composition of the polar fraction, the degree of change in fatty acids, or $\left(\mathrm{E}_{1 \%}{ }^{1 \mathrm{~cm}}\right)$ at $\lambda=233$ and $270 \mathrm{~nm}$ and $\left(\mathrm{E}_{10 \%}{ }^{\mathrm{cm}}\right)$ values.

Among the convective methods preferred in scope of the analyzed physicochemical properties of beans and the properties of cocoa butter is roasting $\mathrm{T}=135^{\circ} \mathrm{C}$ in "dry" air. In terms of the fat remaining in the kernel of cocoa beans the most favorable was the method of roasting in air with higher humidity, however, too long a heat treatment adversely affected the properties of the fat extracted from the bean.

\section{ACKNOWLEDGEMENT}

The authors thank the Polish Ministry of Education and Science for its financial support (Grant No. 5 P06G 023 19) of this research.

\section{REFERENCES}

Asep EK, Jinap S, Tan TJ, Russly AR . 2008. The effects of particle size, fermentation and roasting of cocoa nibs on supercritical fluid extraction of cocoa butter. $J$. Food Engineering 85, 450-458.

Albi T, Lanzón A, Guinda A, León M, Pérez-Camino MC. 1997. Microwave and conventional heating effects on thermooxidative degradation of edible fats. J. Agric. Food Chem. 45, 3795-3798.

Bednarski W. 1986. General Technol. Food. Ed. ART Olsztyn, 175.
Belitz H D, Grosch W. 1999. Cocoa and Chocolate. In Food Chemistry 2nd ed., Springer-Verlag Berlin, 894903.

Benz K. Available [2002]. Debacterization of cocoa beans gains increasing acceptance. http://www.buhlergroup. com/sc/en/publikationen.asp

Brito ES, García NHP, Gallao ML, Cortelazzo AL. 2000. Structural and chemical changes in cocoa (Theobroma cacao $\mathrm{L}$ ) during fermentation, drying and roasting. $J$. Sci. Food Agric. 81, 281-288.

Brito ES. 2002. Effect of glucose and glycine addition to cocoa mass before roasting on Maillard precursor consumption and pyrazine formation. J. Sci. Food Agric. 82, 534-537.

Chaiseri S, Dimick P. 1989. Lipid and hardness characteristics of cocoa butters from different geographic regions. J. Am. Oil Chem. Soc. 66, 1771-1776.

Cossignani L, Simonetti M, Neri A, Damiani P. 1998. Changes in olive composition due to microwave heating. J. Am. Oil Chem. Soc. 75, 931-937.

Deutsche Gesellschaft fur Fettwissenschaft: DGF Standard Method C III 18 (1991) Determination of esterbound 3-chloropropane-1, 2-diol (3-MCPD esters) and 3-MCPD forming substances in fats and oils by means of GC-MS.

Eung-Jung-Lee; Sang-Hyun-Yoon. 2000. Changes in flavor components during microwave roasting of cocoa mass. J. Korean Soc. of Food and Nutritional 29, 384-388 - FSTA 2000-10-KO285.

Fadini AL, Gilabert MV, Pezoa NH, Marsaioli A., Jr. 1997. A study of a continuous roasting process for cocoa using microwaves. Engineering and Food at ICEF 7ed. Jowitt Part C, Academic Press, Sheffield, 49-52.

Faillon, G., Maloney E. 1976. New uses of microwave power in the food industry. Journal of Microwave Power 11, 210.

Farag RS. 1994. Influence of microwave and conventional heating on the quality of lipids in model and food systems. Fat Sci. Technol. 6, 215-222.

Farag RS, El-Baroty G, Abd-El-Aziz N, Basuny AM. 1997. Influence of microwaves on olive oil quality. Grasas Aceites 48, 397-404.

Finken H. 1996. New Thermal Cocoa Process. Food Marketing Technol. 4, 25-27.

Fouert I, Vanrolleghem PA, Thas O, Dewettinck K. 2004. Influence of chemical composition on the isothermal cocoa butter crystallization. J. Food Sci. 9, E478-E487.

ING STM: 1990. Moisture determination of cocoa beans by microwave oven. Petranika 13, 67-72

Jinap S, Wan Rosli WI, Russly AR, Nordin LM. 1998. Effect of roasting time and temperature on volatile component profiles during nib roasting of cocoa beans (Theobroma cacao). J. Sci. Food Agric. 77, 441-448.

Kołożyn-Krajewska D. 1992. Microwave processing of food in catering and hausehold. Przemyst Spożywczy 11, 286-288.

Krełowska -Kułas M. 1993. Determination of quality of food products. Ed. PWE, Warsaw 76-80, 272-274.

Krysiak W. 2002. Roasting conditions and cocoa bean quality. Acta Agrophysica 77, 51-60.

Krysiak W, Iciek J, Motyl-Patelska L. 2003. Effect of roasting conditions on selected physicochemical properties of roasted cocoa beans. Inżynieria Chemiczna i Procesowa 24, 509-523.

Krysiak W, Motyl-Patelska L. 2005. Effect of roasting conditions on a degree of migration of cocoa butter 
from nib to shell. Inżynieria Chemiczna i Procesowa 26, 817-829.

Krysiak W. 2006. Influence of roasting conditions on coloration of roasted cocoa beans. J. Food Engineering 77, 449-453.

Lee SY, Yoo SS, Lee MJ, Kwon IB. 2001. Optimization of nibs roasting in cocoa bean processing with Lottebetter taste and color process. Food Sci. Biotechnol. 10, 286-293.

Minifie B W. 1989. Chocolate, cocoa and confectionery. In Science and Technology. Third Edition. Chapman \& Hall, London \& New York.

Mudgett R E. 1989. Microwave food processing. Food Technol. 43, 117-126.

Mujumdar, A S. 1995. Superheated steam drying. In Handbook of Industrial Drying (ed. A.S. Mujumdar), Marcel Dekker, New York, 1071-1086.

Nebesny E, Rutkowski J. 1998. Effect of roasting and secondary fermentation on cocoa bean enrichment. Pol. J. Food Nutr. Sci. 48, 437-444.

Oomah BD., Liang J, Godfrey D, Mazza G. 1998. Microwave heating of grape-seed: effect on oil quality. J. Agric. Food Chem. 46, 4017-4021.

Őzdemir M., Açkurt, F., Yildiz, M., Biringen, G., et. al. 2001. Effect of roasting on some nutrients of hazelnuts (Corylus Avellena L.). Food Chem. 73, 185-190.

PATENT SWISS,. nr CH 665735A. Lausanne, Switzerland 03.061985

Pawłowicz R, Drozdowski B. 1997. Qualitative and quantitative analysis of frying fats by HPSEC method. Tłuszcze Jadalne 32, 71-80.

PN-A-88030:1998 Standard Method. Determination of temperatures of softening and complete clarity.

PN-A-88035:1998 Standard Method. Determination of viscosity and Casson yield of different cocoa masses.

PN-A-88113:1998 Standard Method. Confectionery semi-finished products. Cocoa beans semi-finished products.

PN EN ISO 5509:2000 Standard Method. Oils and vegetable and animal fats. Preparing esters of methylic fatty acids.

Redgewell RJ, Trovato V. Curti D. 2003. Cocoa bean carbohydrates: roasting-induced changes and polymer interactions. Food Chem. 80, 511-516.
Sandoval AJ, Barreiro JA. 2002. Water sorption isotherms of non - fermented cocoa beans (Theobroma cacao). J. Food Engineering 51, 119-123.

Shamsuddin S, Dimick PS. Proceedings of Cacao Biotechnology Symposium, ed. by P.S. Dimick, Dept. Food Sci. University Park, PA, 1986, p.55.

Shukla VKS. 1995. Cocoa butter properties and quality. Lipid Technology May, 54-57.

Stobińska H, Krysiak W, Nebesny E, Gocałek J. 2001. Microbial contamination of roasted cocoa bean. Properties of Water in Foods. XIlth Seminar. Warszawa, 134-142.

Stobińska H, Krysiak, W., Nebesny E, Kozanecka E. 2006. Effects of convective roasting conditions on microbial safety of cocoa beans. Acta Agrophysica 132, 239-248.

Świechowski, Cz. 1996. Confectionery. Roasting of cocoa beans-comparison of methods. Przeglad Piekarski i Cukierniczy 4, 20-22.

Tan C P, Che Man Y B; Jinap S, Yusoff M S A. 2001. Effects of microwave heating on changes in chemical and thermal properties of vegetable oils. J. Am. Oil Chem. Soc. 78, 1227-1232.

Trojanowska K, Trojan E. 1999. Effects of raw material quality, manufacturing technology and microbial contamination on production of powdered cocoa. Przemysł Spożywczy 12, 42-45.

Tynek M, Hazuka Z, Pawłowicz R, Dudek M. 2001. Changes in the frying medium during deep-frying of food rich in proteins and carbohydrates. J. Food Lipids 8, 251-261.

Yoshida H, Kajimoto G. 1994. Microwave heating affects composition and oxidative stability of sesame (Sesamum indicum) oil. J. Food Sci. 59, 613-616.

Yoshida H, Mieno A, Takagi S, Yamaguchi M, Kajimoto G. 1995. Microwave roasting effects on acyl lipids in soybeans at different moisture content. J. Food Sci. 60, 801-805.

Yoshida H, Takagi S. 1997. Effects of seed roasting temperature and time on quality characteristics of sesame (Sesamum indicum) oil. J. Sci. Food Agric. 75, 19-26. 